\title{
Understanding SARS-CoV-2 Infection and Dynamics with Long Term Wastewater based Epidemiological Surveillance
}

\author{
Athmakuri Tharak ${ }^{1 \dagger}$, Harishankar Kopperi ${ }^{1,3 \dagger}$, Manupati Hemalatha ${ }^{1,3 \dagger}$, Uday $\operatorname{Kiran}^{2,3, \dagger}$, \\ C. G. Gokulan ${ }^{2 \dagger}$, Shivranjani Moharir ${ }^{2 \dagger}$, Rakesh K Mishra ${ }^{2,3, *}$, S Venkata Mohan ${ }^{1,3, *}$
}
${ }^{1}$ Bioengineering and Environmental Sciences Lab, Department of Energy and Environmental Engineering (DEEE), CSIR-Indian Institute of Chemical Technology (CSIR-IICT), Hyderabad-500007, India

${ }^{2}$ CSIR-Centre for Cellular and Molecular Biology (CSIR-CCMB), Hyderabad-500007, India,

${ }^{3}$ Academy of Scientific and Innovative Research (AcSIR), Ghaziabad-201002, India

$\dagger$ These authors contributed equally to the work

*Corresponding authors

Correspondence should be addressed to vmohan_s@yahoo.com or mishra@ccmb.res.in 


\begin{abstract}
Wastewater-based epidemiology (WBE) of SARS-CoV-2 emerged as an advantageous method to study the infection dynamics at substantial population level. A temporal glimpse at sewage viral genome helps as diagnostic tool to understand the viral spread at community level. In this study, for the long-term epidemiological surveillance, we monitored the SARSCoV-2 genetic material in domestic sewage by adopting the longitudinal sampling to represent a selected community ( 1.8 lakhs population which occupies $1.79 \%$ of the total population of Hyderabad city) to understand the dynamics of infection. Dynamics and spread of COVID-19 outbreak within the selected community were achieved by studying the longitudinal sampling for a specific period of time. WBE also promotes clinical scrutiny along with disease detection and management, in contrast to an advance warning signal to anticipate outbreaks.
\end{abstract}

Key words: RNA copies, E-Gene, Community surveillance, Wastewater, Enteric virus 
medRxiv preprint doi: https://doi.org/10.1101/2021.03.15.21253574; this version posted March 16, 2021. The copyright holder for this preprint (which was not certified by peer review) is the author/funder, who has granted medRxiv a license to display the preprint in perpetuity.

All rights reserved. No reuse allowed without permission.

\section{Introduction}

The diagnostic aids, equipment and facilities were phenomenally improved since the pandemic of SARS-Cov-2 emergence, besides the surveillance of SARS-CoV-2 by clinical data employing swab samples from person to person in critical periods of the pandemic is a challenge to understand spread among the communities (Asgar et al., 2014; O'Reilly et al., 2020). Wastewater based epidemiological study (WBE) is being conceived as one of the standard protocols that help to infer the dynamics and infection of the SARS-CoV-2 and its state of severity among the community (Xagoraraki and O'Brien, 2020; Shaw et al., 2020; Randazoo et al., 2020; Venkata Mohan et al., 2021). WBE data will assist new viruses to be detected in a community previous to clinical recognition that allows impart the preventive measure and precautions among the community to resist the outbreak (Casanova et al., 2015; Brainard et al., 2017; Torrey et al., 2019). The ability of SARS-CoV-2 to infect the gastrointestinal tract (GI) in addition to the bronchial inflammation is well reported (Ahmed et al., 2020a; Wu et al., 2020; Ahmed et al., 2020b; Wurtzer et al., 2020; La Rosa et al., 2020; Medema et al., 2020; Usman et al., 2020). The design of the sampling protocol is a crucial factor to detect the COVID-19 genetic material in the wastewater. A load of viral material in sewage alters temporally based on the time of defecation frequencies and sampling (Weidhaas et al., 2020; Nakamura et al., 2015). Diverse viral load shedding from the affected community, converging of household wastewater and industrial effluents and time of sampling could affect the detection of the viral genome in the sewage, however, WBE provides a range of information to predict the dynamics of infection with the design of sampling protocol (Ahmed et al., 2020; Wurtzer et al., 2020; Venugopal et al., 2020; Kopperi et al., 2021; Daughton et al., 2018; Lednicky et al., 2020; Venkata Mohan et al., 2021; Quilliam et al., 2020). Different independent SARS-CoV-2 WBE studies followed different water sampling and processing methods to detect the SARS-CoV-2 RNA in sewage 
(Daughton 2018; Lednicky et al., 2020; Venkata Mohan et al., 2021; Quilliam et al., 2020), The grab sampling method can be used in remote areas and even in poor sewage system conditions, which helps in better surveillance (Kopperi et al., 2021). These WBE methods will help to monitor surveillance in the agency area where proper infrastructure and hospitality lacks. A true sampling at the selected station and data obtaining from the study provides information about the spread and impact of the severity that helps to give the alarming signal to the corresponding community (Mao et al., 2020; Hart et al., 2020; Hemalatha et al., 2021).

In the present study, an attempt was made to investigate the persistence and dynamics of SARS-CoV-2 in domestic sewage by conducting longitudinal sampling over a period of six months (July 2020 to February 2021 excluding the rainfall event months i.e., August 2020 and September 2020) in a selected community representing 1.8 lakhs of population.

\section{Methodology}

\subsection{Sampling area}

The study area represents a community with $\sim 1.8$ lakhs population covering Tarnaka, HMT Nagar, Lalaguda and Nacharam as part of Greater Hyderabad, Telangana (State), India. The selected community discharges 18 MLD of domestic wastewater (sewage) flows through the main drain starting from Lalaguda finally covering at sampling point T10 before STP inlet (Fig 1). Various laterals drain joins the main drain covering the adjoining domestic settlements. Eight sampling points were selected across the drain system to comprehensively represent the majority of lateral drains (Fig. 1). Sampling points were selected in such a way to cover the entire community sewage network. Samples were collected at the lateral drain 
medRxiv preprint doi: https://doi.org/10.1101/2021.03.15.21253574; this version posted March 16, 2021. The copyright holder for this preprint (which was not certified by peer review) is the author/funder, who has granted medRxiv a license to display the preprint in perpetuity.

All rights reserved. No reuse allowed without permission.

before getting merged into the main drain. The main sewage drain of the community finally gets discharged into the sewage treatment plant (STP; 10 MLD) located at Nacharam.

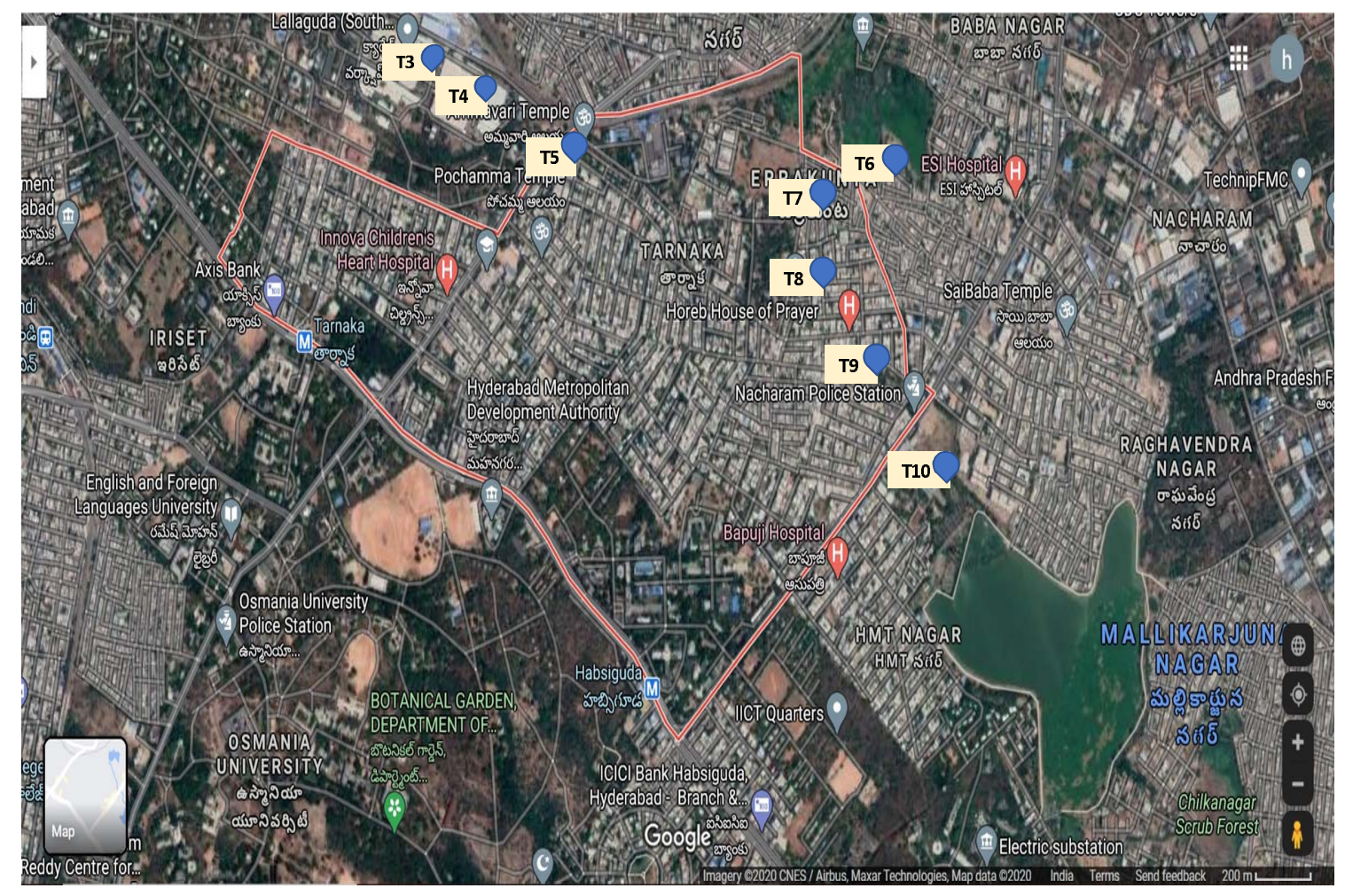

Fig.1. Map showing the point of sample collection (Tarnaka and Nacharam) (Courtesy: Google Map)

\subsection{Details of Sampling}

Grab sampling protocol was followed to sample domestic wastewater at the selected sampling stations (APHA 2017). Samples were collected at 8:00 to 8:30 am on the day wherein there was no rainfall event, 2 days prior to sampling day also. Grab samples were collected on a weekly and monthly basis. Total of eight samples were collected for weekly monitoring starting from 07-10-2020 (Week 1), 28-10-2020 (Week 4), 04-11-2020 (Week 5), 11-11-2020 (Week 6) and 18-11-2020 (week 7). Samples were not collected during Week 2 and Week 3 due to heavy rainfall events that occurred leading to the overflow of all sewage drains. Monthly samples were sampled at terminal covering point of the main drain (T10) 
medRxiv preprint doi: https://doi.org/10.1101/2021.03.15.21253574; this version posted March 16, 2021. The copyright holder for this preprint (which was not certified by peer review) is the author/funder, who has granted medRxiv a license to display the preprint in perpetuity.

All rights reserved. No reuse allowed without permission.

starting from July 2020 and planned to collect over the 6 months continuously, but due to the monsoon rainfall in early august (14/08/2020 to 24/09/2020 and 10/10/2020 to 21/10/2020), sampling was paused and restarted from October 2020 continued till March 2021 (Table 1).

Table 1: Details of Sampling with reference to time of weekly and monthly samples (As shown in Fig 1)

\begin{tabular}{|c|c|c|c|c|c|}
\hline \multicolumn{6}{|c|}{ Weekly Monitoring } \\
\hline $\begin{array}{l}\text { S. } \\
\text { No. }\end{array}$ & Sampling Point & Location & Drain & $\begin{array}{c}\text { Sample } \\
\text { Code }\end{array}$ & $\begin{array}{l}\text { Sampling date } \\
\text { and time }\end{array}$ \\
\hline 1 & South Lalaguda (Point -3 ) & South Lalaguda & Lateral Drain & T3 & \multirow{6}{*}{$\begin{array}{l}07 / 10 / 2020 \\
28 / 10 / 2020 \\
04 / 11 / 2020 \\
11 / 11 / 2020 \\
18 / 11 / 2020\end{array}$} \\
\hline 2 & South Lalaguda (Point - 4) & South Lalaguda & Main Drain & $\mathrm{T} 4$ & \\
\hline 3 & Lalapet & Lalapet Bridge & Main Drain & T5 & \\
\hline 4 & Tarnaka (Drain- 1) & $\begin{array}{c}\text { Near Pedda } \\
\text { Cheruvu (Small) }\end{array}$ & Main Drain & T6 & \\
\hline 5 & Tarnaka (Drain- 2 & Errakunta & Lateral Drain & $\mathrm{T} 7$ & \\
\hline 6 & Tarnaka (Drain- 3) & VST Colony & Lateral Drain & $\mathrm{T} 8$ & \\
\hline 7 & Tarnaka (Drain- 4) & $\begin{array}{c}\text { Behind } \\
\text { Nacharam PS }\end{array}$ & Lateral Drain & T9 & \multirow[t]{2}{*}{$8: 00$ to $8: 30$ am } \\
\hline 8 & Nacharam (Drain-1) & Inlet to STP & Main Drain & $\mathrm{T} 10$ & \\
\hline \multicolumn{6}{|c|}{ Monthly Monitoring } \\
\hline & & \multicolumn{2}{|c|}{ Location; Point of Drain } & \multicolumn{2}{|c|}{$\begin{array}{l}\text { Sampling date } \\
(8: 00 \text { to } 8: 30 \mathrm{am})\end{array}$} \\
\hline 1 & Nacharam & \multicolumn{2}{|c|}{$\mathrm{T} 10$} & \multicolumn{2}{|c|}{$22-07-2020$} \\
\hline \multirow[t]{2}{*}{2} & All (Eight) sampling points & \multicolumn{2}{|c|}{$\mathrm{T} 3$ to $\mathrm{T} 10$} & \multicolumn{2}{|c|}{$\begin{array}{l}7-10-2020 \\
4-11-2020\end{array}$} \\
\hline & Nacharam & \multicolumn{2}{|c|}{$\mathrm{T} 10$} & \multicolumn{2}{|c|}{$11-12-2020$} \\
\hline 3 & Five sampling points & \multicolumn{2}{|c|}{ T6-T10 } & \multicolumn{2}{|c|}{$\begin{array}{l}20-01-2021 \\
13-02-2021 \\
02-03-2021\end{array}$} \\
\hline
\end{tabular}

\subsection{Sample collection and processing}

Samples were collected with all the safety measures as discussed in Hemalatha et al., 2021.

The sample container was slightly lowered in the opposite direction of flow with partial immersion. After sampling the external surface of the container is disinfected with $70 \%$ ethanol to prevent contamination and sealed with plastic bags, labeled and transported $(4 \pm 1$ ${ }^{\circ} \mathrm{C}$ ) immediately to the lab and stored at $4{ }^{\circ} \mathrm{C}$ until further processing. Samples were processed within $12 \mathrm{~h}$. 


\subsection{Processing of Samples}

Collected samples were subjected to the gravity filtration using $1 \mathrm{~mm}$ filter papers to remove the larger debris followed by secondary filtration with $0.2 \mu \mathrm{m}$ filtration units (Nalgene® vacuum filtration system) to remove other fine particles and pathogens (Hemalatha et al., 2021). $60 \mathrm{~mL}$ of the total filtrate was concentrated to $\sim 600 \mu 1$ using $15 \mathrm{~mL} 30 \mathrm{kDa}$ Amicon® Ultra-15 (Merck Millipore) by ultra-filtration (4000 rpm; $4{ }^{\circ} \mathrm{C} ; 10 \mathrm{~min}$ ). $150 \mu \mathrm{L}$ of the concentrated sample was used for RNA extraction. All the sample processing and detection experiments were performed in a Biosafety level 2 (BSL-2) laboratories.

\subsection{RNA extraction and RT-PCR}

RNA was extracted from the concentrated samples using the Viral RNA isolation kit (QIAamp, Qiagen) with provided manufactures protocol. DNA/RNA cross-contamination was avoided by using sterile equipment and RNase-free water for the RNA extraction (Hemalatha et al., 2021; Kopperi et al., 2021). Isolated SARS-CoV-2 RNA was quantified by using FDA (Food and Drug Administration, USA Government) approved RT-PCR Detection Kit (Shanghai Fosun Long March Medical Science Co., Ltd, China). Fosun RT-PCR containing the primers and chromophore probes encoding for the envelope protein-coding gene (E-gene; ROX), nucleocapsid gene (N-gene; JOE), and open reading frame1ab (ORF1ab; FAM) of SARS-CoV-2. RT-PCR reaction procedure includes two initial cycles, Reverse transcription $\left(50^{\circ} \mathrm{C}\right.$ for $\left.15 \mathrm{~min}\right)$ and the Initial denaturation $\left(95^{\circ} \mathrm{C}\right.$ for 3 minutes $)$ followed by 45 cycles at $95^{\circ} \mathrm{C}$ for 5 seconds and $60^{\circ} \mathrm{C}$ for 40 seconds. Signals from the probes (FAM (ORF1ab), JOE (N gene), ROX (E gene), and CY5 (Internal reference)) were collected by the fluorescence channels at $60^{\circ} \mathrm{C}$. Both positive and negative controls of the fosun RT-PCR kit were included in all the amplifications. $\mathrm{C}_{\mathrm{T}}$ values in the positive controls 
match with given manufactured data and no $\mathrm{C}_{\mathrm{T}}$ was observed in negative control that states the devoid of contamination. All the samples done were analyzed in triplicate.

\subsection{Statistical methods and data management}

To calculate the number of RNA copies per litre of collected domestic wastewater samples, linear fit equation of the E-gene was employed and RNA copies per liter wastewater was calculated (Hemalatha et al., 2021).

\section{Results and Discussion}

\subsection{Weekly Sample Analysis for SARS-CoV-2}

SARS-CoV-2 genetic material was detected in all the 40 samples collected at 8 sampling stations over the window period of five weeks from $07 / 10 / 2020$ to $18 / 11 / 2020$ with variable loads. Amplification of three SARS-CoV-2 target genes, namely, E gene, $\mathrm{N}$ gene, and ORF1ab was detected in all the samples. Apart from the $\mathrm{C}_{\mathrm{T}}$ values, to predict the SARSCoV-2 viral load in domestic sewage, the RNA copy number was calculated considering the linear fit drawn from the standard curve of the E-gene, in our previous work (Hemalatha et al., 2021). $\mathrm{C}_{\mathrm{T}}$ values (average) of E-gene, $\mathrm{N}$-gene, and ORF1ab at the initial sampling point (South Lalaguda lateral drain; T3) were $28.35 \pm 1.27 \%, 26.85 \pm 1.30 \%$, and $27.89 \pm 0 \%$, respectively with five-week average RNA copies of 23,470 Copies/L. The extended point to the $\mathrm{T} 3$, that is the $\mathrm{T} 4$ sample (South Lalaguda Main drain) showed $\mathrm{C}_{\mathrm{T}}$ values (average) of $27.16 \pm 1.29 \%, 25.39 \pm 1.65 \%$, and $21.01 \pm 0.32 \%$ for E-gene, N-gene, and ORF1ab, respectively with the RNA copy number of 54,135 Copies/L. An increase in the RNA copy number at the T4 might be due to the converging of the lateral drains containing domestic sewage discharge into the main drain. Wastewater from the main drain (T4) flows continuously till the end of the selected longitudinal sampling point (Nacharam Inlet to STP; 
T10). The third sampling point located at Lalapet Bridge (T5) showed relatively less $\mathrm{C}_{\mathrm{T}}$ values (Average; $\mathrm{E}-$ gene, 28.73 $\pm 1.04 \% ; \mathrm{N}$-gene, 27.54 $\pm 1.82 \%$; ORF1ab were, $28.72 \pm 0.93 \%$ ) compared to T3 and T4 corresponding to 17,954 RNA Copies/L. Even though the main drain stream continued from the earlier sampling point, the number of RNA copies was reported less at the T5 that might be due to the conflate of diary processing effluents with excessive surfactants (chemical) discharged into the drain that may disintegrate the viral RNA material. Similar observations were reported elsewhere (Yonar et al., 2018; Barcelo 2020; Westhaus et al., 2021). Downstream T5, the domestic sewage overflow from Pedda Cheruvu (Lake) and discharges into the main drain (T6). $\mathrm{C}_{\mathrm{T}}$ values (average) at $\mathrm{T} 6$ was recorded to be $27.42 \pm 3.36 \%, 26.28 \pm 4.68 \%$, and $27.14 \pm 0 \%$ for E-gene, N-gene, and ORF1ab, respectively with RNA copies of 45050 Copies/L. Relative increment in viral load was evident with T6 samples compared to T5. In addition to samples collected in the main drain, we have collected samples of lateral drains that were flowing from the set of communities located around the main drain and this flow finally merges into the main drain. These lateral drain sewage samples depicted marginally low values of SARS-CoV-2 load than the main drain.

$\mathrm{C}_{\mathrm{T}}$ values (average) of $\mathrm{E}$ - gene, $\mathrm{N}$-gene, and ORF1ab of the samples collected at $\mathrm{T} 7$ (Errakunta lateral drain) was $28.46 \pm 2.39 \%, 26.58 \pm 2.67 \%$, and $21.61 \pm 1.31 \%$ respectively with 21757 Copies/L. Similarly, the two lateral drains T8 (VST lateral drain) and T9 (Nacharam lateral drain) recorded $C_{T}$ values (average) of 26.03 $\pm 1.96 / 25.41 \pm 1.50 \%$ (E-gene), $24.53 \pm 3.38 \% / 23.37 \pm 3.34 \%$ (N-gene) and $20.06 \pm 1.21 \% / 19.56 \pm 1.33 \%$ (ORF1ab) with higher RNA copies 119391 and 184664 RNA Copies/L, respectively. T10 samples representing the terminal point of main drain where the flow of all the previous sampling points converges showed $\mathrm{C}_{\mathrm{T}}$ values that was almost an average of those obtained from other sampling sites 
individually $\left(\mathrm{C}_{\mathrm{T}}\right.$ values (average): $27.24 \pm 1.84 \% \quad$ (E-gene), $25.71 \pm 1.28 \% \quad$ (N-gene), $21.33 \pm 0.48 \%(\mathrm{ORF} 1 \mathrm{ab}))$ with 51182 RNA Copies/L. $\mathrm{C}_{\mathrm{T}}$ values of E-gene in all the sampling points range between $25.41 \pm 1.50 \%$ and $28.73 \pm 1.04 \%$ with an average of $27.35 \pm 1.83 \%$ (Table 2). Similarly, the $\mathrm{C}_{\mathrm{T}}$ values of the $\mathrm{N}$-gene and ORF1ab was observed between $23.37 \pm 3.34 \%$ to $27.54 \pm 1.82 \%$ and $19.56 \pm 1.33 \%$ to $28.72 \pm 0.93 \%$ respectively having an average of $25.78 \pm 2.48 \%$, and $23.42 \pm 0.7 \%$ (Table 2). Along with the cumulative average, individual three genes average value of sampling points from T3 to T9 correlated with the $\mathrm{C}_{\mathrm{T}}$ values observed at last sampling point T10. The well-defined correlation states that the comprehensive epidemiological analysis of the selected community by considering the terminal discharge point of the drain (T10).

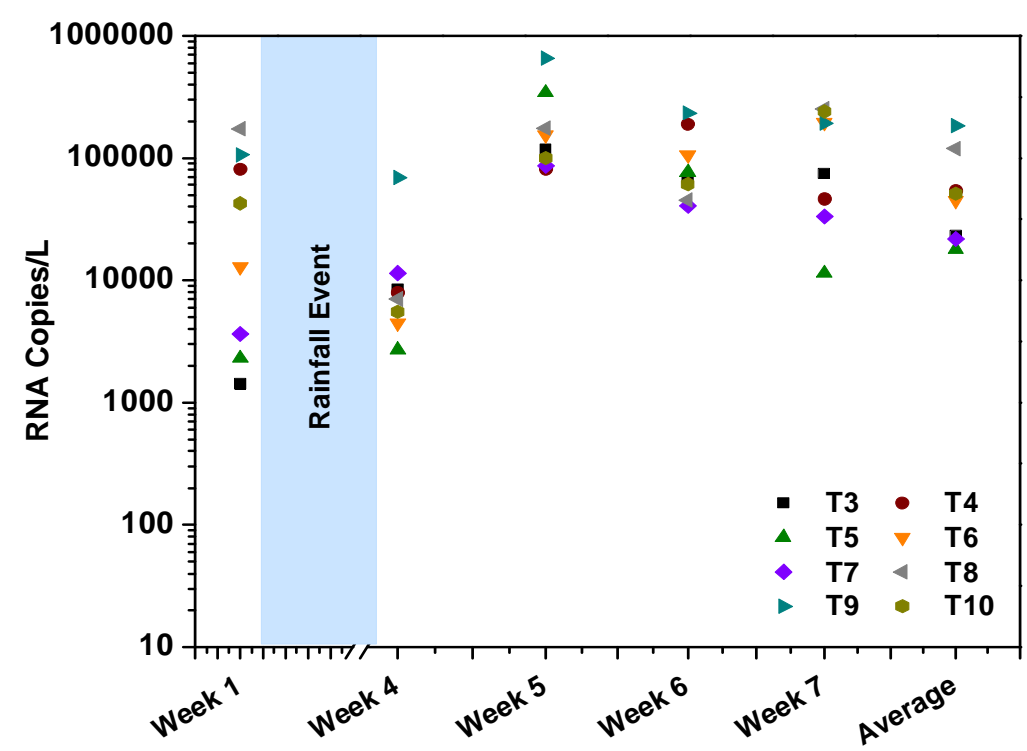

Fig. 2: RNA copies calculated for based on linear fit equation of E-gene.

Table 2 depicts comprehensive data about the five-week average $\mathrm{C}_{\mathrm{T}}$ values (Individual genes) of a particular sampling point, cumulative average of all points in a week along with RNA copy number. The Higher RNA copies of 184,664 RNA Copies/L were observed at sampling station T9 (Tarnaka lateral drain) where the lowest E-gene CT of $25.41 \pm 1.50 \%$ depicted. At the sampling point T7 (Errakunta lateral drain) a lower viral load of 17,954 RNA Copies/L was observed (Fig. 2; Table 2). On average 64,700 RNA Copies/L was observed in all the 8 
medRxiv preprint doi: https://doi.org/10.1101/2021.03.15.21253574; this version posted March 16, 2021. The copyright holder for this preprint (which was not certified by peer review) is the author/funder, who has granted medRxiv a license to display the preprint in perpetuity.

All rights reserved. No reuse allowed without permission.

points (Table 2). During the weekly longitudinal monitoring, there was not much difference noticed with the temporal (weekly) variation and therefore, one-day sampling in a week might provide comprehensive/representative load over the wind period of one week.

Table 2: SARS-CoV-2 RNA load in weekly monitoring sewage samples

\begin{tabular}{|c|c|c|c|c|}
\hline $\begin{array}{c}\text { Sample } \\
\text { Code }\end{array}$ & E $^{\text {gene }}{ }^{*}$ & N gene $^{*}$ & ORF1ab $^{*}$ & $\begin{array}{c}\text { RNA } \\
\text { copies/1L }^{* * * *}\end{array}$ \\
\hline T3 & $28.35 \pm 1.27 \%$ & $26.85 \pm 1.30 \%$ & $27.89 \pm 0 \%$ & 23470 \\
\hline T4 & $27.16 \pm 1.29 \%$ & $25.39 \pm 1.65 \%$ & $21.01 \pm 0.32 \%$ & 54135 \\
\hline T5 & $28.73 \pm 1.04 \%$ & $27.54 \pm 1.82 \%$ & $28.72 \pm 0.93 \%$ & 17954 \\
\hline T6 & $27.42 \pm 3.36 \%$ & $26.28 \pm 4.68 \%$ & $27.14 \pm 0 \%$ & 45050 \\
\hline T7 & $28.46 \pm 2.39 \%$ & $26.58 \pm 2.67 \%$ & $21.61 \pm 1.31 \%$ & 21757 \\
\hline T8 & $26.03 \pm 1.96 \%$ & $24.53 \pm 3.38 \%$ & $20.06 \pm 1.21 \%$ & 119391 \\
\hline T9 & $25.41 \pm 1.50 \%$ & $23.37 \pm 3.34 \%$ & $19.56 \pm 1.33 \%$ & 184664 \\
\hline T10 & $27.24 \pm 1.84 \%$ & $25.71 \pm 1.28 \%$ & $21.33 \pm 0.48 \%$ & 51182 \\
\hline Average & $\mathbf{2 7 . 3 5} \pm \mathbf{1 . 8 3 \%}$ & $\mathbf{2 5 . 7 8} \pm \mathbf{2 . 4 8 \%}$ & $\mathbf{2 3 . 4 2 \pm \mathbf { 0 . 7 } \%}$ & $\mathbf{6 4 7 0 0}$ \\
\hline
\end{tabular}

\section{*Represent $\bar{X}+\mathrm{RSD}$; **Average $\mathbf{C}_{\mathrm{T}}$ of $\mathbf{E}, \mathbf{N}$ and ORF1ab genes; ***RNA copies (based on $\mathbf{E}$ gene) were calculated based on the linear fit equation.}

\subsection{Monthly Sample Analysis}

Apart from the weekly monitoring, the dispersive and dynamic viral presence in the domestic sewage was also assessed with long-term (monthly) analysis by selecting the final drain point (T10) as a sampling station along with some other stations (T6 to T10). Presence of the three target genes were detected in all the 7 months' samples with variable RNA copy numbers. In July, the $\mathrm{C}_{\mathrm{T}}$ values of the E-gene, N-gene, and ORF1ab were $27.38 \pm 0.36 \%, 26.12 \pm 1.38 \%$, and $28.02 \pm 1.92 \%$, respectively with 46,527 RNA Copies/L. After the first month of sampling, multiple rainfall events occurred due to the seasonal monsoon across the Deccan plateau. Because of overflow in the drains, sample collections were paused in August and September and were resumed after the flow became normal. $\mathrm{C}_{\mathrm{T}}$ values of the E-gene, $\mathrm{N}$-gene, and ORF1ab were observed to be $27.5 \pm 2.65 \%, 26.82 \pm 0.63 \%$, and $27.34 \pm 4.10 \%$ with 42,772 RNA Copies/L which is more or less similar to July viral load analysis data. As weekly sampling was performed during October, samples collected at all selected longitudinal points were analyzed and the average values of individual genes of the eight points (T3 to T10; 
$\mathrm{C}_{\mathrm{T}}$ values (average) $28.34 \pm 1.25$ (E-gene), 27.24 \pm 1.25 (N-gene), 27.92 \pm 2.09 (ORF1ab) is reported. Specifically, the samples collected during November 2020 showed lesser $\mathrm{C}_{\mathrm{T}}$ values (25.03 $\pm 0.88 \%$ (E-gene), $23.26 \pm 0.73 \%$ (N-gene), $24.41 \pm 0.86 \%$ (ORF1ab) and a higher viral load (241,722 RNA Copies/L) compared to other monthly samples. This suggests the possibility of high infection rate during November 2020. In December, a considerable drop in the viral load (20,624 RNA Copies/L; $\mathrm{C}_{\mathrm{T}}$ values $(28.5 \pm 0.21 \%$ (E-gene), $26.84 \pm 0.73 \%(\mathrm{~N}-$ gene), $27.19 \pm 0.49 \%(\mathrm{ORF} 1 \mathrm{ab}))$ was recorded indicating the tapering of infection within the community, suggesting a decrement in the infection rate. To maintain the accuracy of sampling, from January 2021 samples were collected in 5 sampling stations among the eight sampling stations. The viral load during January 2021 further reduced (2036 RNA Copies/L; $\mathrm{C}_{\mathrm{T}}$ value- $\quad 30.44 \pm 0.84 \% \quad$ (E-gene), $29.48 \pm 4.81 \% \quad$ (N-gene), $\left.28.99 \pm 2.15 \% \quad(\mathrm{ORF} 1 \mathrm{ab})\right)$. However, compared to January 2021, February 2021 samples showed a marginal increment in viral load (5228 RNA Copies/L with CT of $31.10 \pm 1.98 \%$ (E-gene), $31.23 \pm 2.95 \%(\mathrm{~N}$ gene), $28.77 \pm 2.33 \%$ (ORF1-ab)) and decreased in subsequent month of March-2021(March2021: 2781 RNA Copies/L; $C_{T}$ values, 31.39 $\pm 2.86 \%$ (E-gene), 29.38 $\pm 1.30 \%$ (N-gene), $27.63 \pm 3.38 \%$ (ORF1-ab) (Fig. 3 and Table 4). Among the six months of study, a greater number of samples were analyzed during the months of October and November because of the weekly sampling and monitoring conducted during that period.

Lower RNA copy number was observed from December till the last month of sampling (March-2021). In seven months, window period, $\mathrm{C}_{\mathrm{T}}$ values of E-gene ranging from $25.03 \pm 0.88 \%$ to $31.84 \pm 0.83 \%$. Whereas $\mathrm{N}$-gene and ORF1ab ranging between $23.26 \pm 0.73 \%$ to $30.45 \pm 2.22 \%$ and $24.41 \pm 0.86 \%$ to $28.89 \pm 2.70 \%$ respectively (Fig. 3; Table 4 ). Temporal variation in the number of infected individuals was observed in our analysis. Such variation might be caused by various factors including infection rate, loss of viral RNA during transit from the source to the sampling site, presence of deteriorating agents in the wastewater 
medRxiv preprint doi: https://doi.org/10.1101/2021.03.15.21253574; this version posted March 16, 2021. The copyright holder for this preprint (which was not certified by peer review) is the author/funder, who has granted medRxiv a license to display the preprint in perpetuity.

All rights reserved. No reuse allowed without permission.

samples, and differences in the amount of virus shed by infected individuals. Reports show a loss of 0.02 to 3000 RNA copies/mL during the passage of faecal matter from the point of defecation to the sewage drain (Foladori et al., 2020).

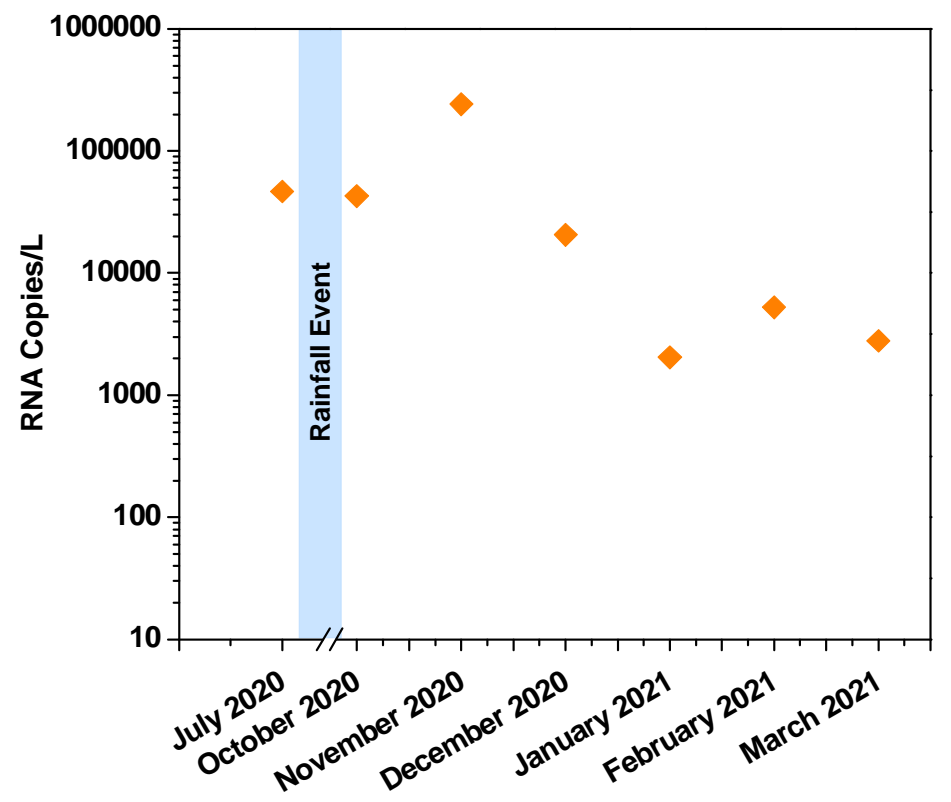

Fig. 3: RNA copies calculated for based on linear fit equation of E-gene. The experiments were performed in triplicates.

Table 4: SARS-CoV-2 RNA load with monthly monitoring domestic sewage samples

\begin{tabular}{|c|c|c|c|c|c|c|c|}
\hline \multirow[b]{2}{*}{$\begin{array}{l}\text { Sample } \\
\text { Code }\end{array}$} & \multicolumn{2}{|c|}{$\begin{array}{l}\text { E gene* } \\
\left(\mathbf{C}_{\mathbf{T}}\right)\end{array}$} & \multicolumn{2}{|c|}{$\begin{array}{l}\text { N gene }^{*} \\
\left(\mathbf{C}_{\mathbf{T}}\right)\end{array}$} & \multicolumn{2}{|c|}{$\begin{array}{c}\text { ORF1ab }^{*} \\
\left(\mathbf{C}_{\mathrm{T}}\right)\end{array}$} & \multirow{2}{*}{$\begin{array}{c}\text { RNA } \\
\text { Copies/L } \mathbf{L}^{* * * *}\end{array}$} \\
\hline & T10 & $\begin{array}{l}\text { Average of } \\
\text { longitudinal } \\
\text { sampling }\end{array}$ & T10 & $\begin{array}{l}\text { Average of } \\
\text { longitudinal } \\
\text { sampling }\end{array}$ & T10 & $\begin{array}{l}\text { Average of } \\
\text { longitudinal } \\
\text { sampling }\end{array}$ & \\
\hline $\begin{array}{l}\text { July } \\
2020\end{array}$ & $27.38 \pm 0.36 \%$ & - & $26.12 \pm 1.38 \%$ & & $28.02 \pm 1.92 \%$ & & 46,527 \\
\hline $\begin{array}{c}\text { October } \\
2020\end{array}$ & $27.5 \pm 2.65 \%$ & $28.34 \pm 1.25$ & $26.82 \pm 0.63 \%$ & $27.24 \pm 1.25$ & $27.34 \pm 4.10 \%$ & $27.92 \pm 2.09$ & 42,772 \\
\hline $\begin{array}{c}\text { November } \\
2020 \\
\end{array}$ & $25.03 \pm 0.88 \%$ & $26.52 \pm 1.04$ & $23.26 \pm 0.73 \%$ & $24.96 \pm 1.54$ & $24.41 \pm 0.86 \%$ & $25.20 \pm 4.27$ & $2,41,722$ \\
\hline $\begin{array}{c}\text { December } \\
2020\end{array}$ & $28.5 \pm 0.21 \%$ & - & $26.84 \pm 0.73 \%$ & - & $27.19 \pm 0.49 \%$ & - & 20,624 \\
\hline $\begin{array}{c}\text { January } \\
2021 \\
\end{array}$ & $31.84 \pm 0.83 \%$ & $30.44 \pm 0.84 \%$ & $29.49 \pm 4.26 \%$ & $29.48 \pm 4.81 \%$ & $28.89 \pm 2.70 \%$ & $28.99 \pm 2.15 \%$ & 2036 \\
\hline $\begin{array}{c}\text { February } \\
2021\end{array}$ & $30.50 \pm 1.30 \%$ & $31.10 \pm 1.98 \%$ & $30.45 \pm 2.22 \%$ & $31.23 \pm 2.95 \%$ & $28.30 \pm 5.48 \%$ & $28.77 \pm 2.33 \%$ & 5228 \\
\hline $\begin{array}{c}\text { March } \\
2021\end{array}$ & $31.39 \pm 2.86 \%$ & $31.38 \pm 1.88 \%$ & $29.38 \pm 1.30 \%$ & $29.53 \pm 1.11 \%$ & $27.63 \pm 3.38 \%$ & $27.12 \pm 3.35 \%$ & 2781 \\
\hline
\end{tabular}

*Represent $\bar{X}+\mathbf{R S D}$; **Average $\mathbf{C}_{\mathbf{T}}$ of $\mathbf{E}, \mathbf{N}$ and ORF1ab genes; ***RNA copies (based on $\mathbf{E}$ gene) were calculated based on the linear fit equation. 


\subsection{Epidemiological Analysis}

Based on the RNA copy number detected in the weekly samples, enteric virus community spread was predicted by considering the volume of sewage discharge as well as the population of the selected community. Estimated numbers of infected individuals in the selected community were calculated based two methods (Ahmed et al., 2020; Hellmer et al., 2014) using two different values for the number of RNA copies shed through faeces $-10^{6}$ and $10^{7}$ RNA copies/mL faeces (Hemalatha et al., 2021; Kopperi et al., 2021). The number of infected individuals in the studied community is based on a total window period of 77 days (which includes 14 days each before and after the sampling period combined with 49 days of sampling period). The window period was selected based on the reports that showed the persistence of SARS-CoV-2 genetic material in the faecal matter of infected individuals before, during, and after the active infection phase (Wu et al., 2020; Woefel et al., 2020; Holshue et al., 2020; Peccia et al., 2020). The probable number of infected individuals in the studied community (77 days window period) was 940 with 171 people being in their active phase of infection. The community under study covers a population of $\sim 1.8$ lakhs which represents $\sim 1.79 \%$ of the total Hyderabad city population. Considering the number of infected individuals in the selected community with 18 MLD domestic sewage flow (i.e. $1 \%$ of total sewage flow of 1800 MLD of Hyderabad city (https://timesofindia.indiatimes.com/city/hyderabad/master-plan-report-on-sewageby-dec-)), extrapolation was made to arrive at the total infected individuals of the city which was calculated to be 94,050 with about 17,100 active phase individuals. The infection rate of 52.2 Person/MLD was derived based on infected individuals and population figures. 
Table 5: Infection rate estimation through the number of people infected (symptomatic, asymptomatic, and recovered) during the sampling window.

\begin{tabular}{|c|c|c|c|c|c|c|c|}
\hline \multirow[b]{2}{*}{ Sample } & \multirow[b]{2}{*}{$\begin{array}{l}\text { Capacity of } \\
\text { the STP } \\
\text { (MLD) }\end{array}$} & \multicolumn{3}{|c|}{$10^{7}$ copies/mL faeces } & \multicolumn{3}{|l|}{$10^{6}$ copies $/ \mathrm{mL}$ faeces } \\
\hline & & $\begin{array}{lr}\text { Per person } \\
\text { contribution to } \\
\text { STP }\end{array}$ & Method 1 & Method 2 & $\begin{array}{l}\text { Per person } \\
\text { contribution to } \\
\text { STP }\end{array}$ & Method 1 & Method 2 \\
\hline $\mathrm{T} 3$ & \multirow{8}{*}{18} & \multirow{8}{*}{67} & 330 & 352 & \multirow{8}{*}{6.7} & 3300 & 3520 \\
\hline $\mathrm{T} 4$ & & & 761 & 812 & & 7613 & 8120 \\
\hline T5 & & & 252 & 269 & & 2525 & 2693 \\
\hline T6 & & & 634 & 676 & & 6335 & 6758 \\
\hline $\mathrm{T} 7$ & & & 306 & 326 & & 3060 & 3264 \\
\hline $\mathrm{T} 8$ & & & 1679 & 1791 & & 16789 & 17909 \\
\hline $\mathrm{T} 9$ & & & 2597 & 2770 & & 25968 & 27700 \\
\hline $\mathrm{T} 10$ & & & 720 & 768 & & 7197 & 7677 \\
\hline \multicolumn{3}{|c|}{$\begin{array}{l}\text { Estimate of infected individuals (for Study Area } \\
\text { with } 18 \text { MLD) }\end{array}$} & 910 & 971 & & 9098 & 9705 \\
\hline \multicolumn{4}{|c|}{ Average estimate of infected individuals } & 940 & & & 9400 \\
\hline \multicolumn{4}{|c|}{$\begin{array}{l}\text { Estimate of the population in active phase of the infection } \\
\text { during the window period of } 77 \text { days }\end{array}$} & 171 & & & 1709 \\
\hline \multicolumn{3}{|c|}{$\begin{array}{l}\text { For } 1800 \text { MLD (on total Sewage Generation of } \\
\text { Hyderabad city) }\end{array}$} & 91,000 & 97,100 & & $9,09,800$ & $9,70,500$ \\
\hline \multicolumn{4}{|c|}{ Average estimate of infected individuals } & 94,050 & & & $9,40,150$ \\
\hline \multicolumn{4}{|c|}{$\begin{array}{l}\text { Estimate of the population in active phase of the infection } \\
\text { during the window period of } 77 \text { days }\end{array}$} & 17,100 & & & $1,70,936$ \\
\hline
\end{tabular}


Using the monthly monitoring data, the number of infected individuals was calculated during each month individually (Table 6). The number of infected individuals in the month of July was recorded as 676 (study area) and 67,606 (total city) with active phase individuals of 322 and 32195. After the rainfall event during August and September months, number of infected individuals reported in October 2020 was more or less similar to that in July 2020, wherein infected/active phase individuals in the study area and the entire city were 622/296 and 62153/26597, respectively. Marginal variation from July to October indicates the consistent spread of the enteric viral load among the community. However, in November 2020, the infection raised significantly (infected/active, 3513/1673 (study area); 351252/167263 (City)). A substantial increment in the number of infected individuals in November 2020 suggests widespread SARS-CoV-2 infection in the community. In subsequent months, December 2020 showed a substantial drop in infection (300/143 Study Area); (29970/14271 City). This decrement was observed in January 2021 with a minimal number of infection [(infected/active, 30/14 (study area); 2958/1409 (Hyderabad)]. However, February 2021 data indicated a minor increment in infected individuals of 76 and 759 in the study area and Hyderabad city, respectively, having an active phase individual of 36 (Selected community) and 3618 (Hyderabad) compared to January 2021 and followed by decreased in march-2021 (41/20 study area; 4100/1952 in city). Altogether, a higher number of infected individuals were reported in the month of November 2020 and the lowest infection was recorded in January 2021 and march-2021. The Infection rate showed more or less similar load from July to Oct with the incremental trend in Nov 2020 followed by a decrement in the next four months (Dec 2020 to Mar 2021). The repeated detection of the viral RNA over the months in sewage indicates infection severity and persistence of SARS-CoV-2. 
WBE studies are effective strategies to track the disease dynamics of viral infections. Longitudinal sampling from the different selected points given an appropriate state of viral infection within the selected community (Alygizakis et al., 2020; Dhama et al., 2021). The number of infected individuals reported in the present study includes pre- and postsymptomatic, asymptomatic, and mildly symptomatic individuals. Associated with clinical data, WBE could provide critical monitoring of SARS-CoV-2 transmission within a community including the beginning, tapering, or reemergence of the virus (Gundy et al., 2009; Ahmed et al., 2020; Elsamadony et al., 2021). 
Table 6: Disease dynamics and Infection rate estimation through the number of people infected (symptomatic, asymptomatic, and recovered) during the sampling window of six months.

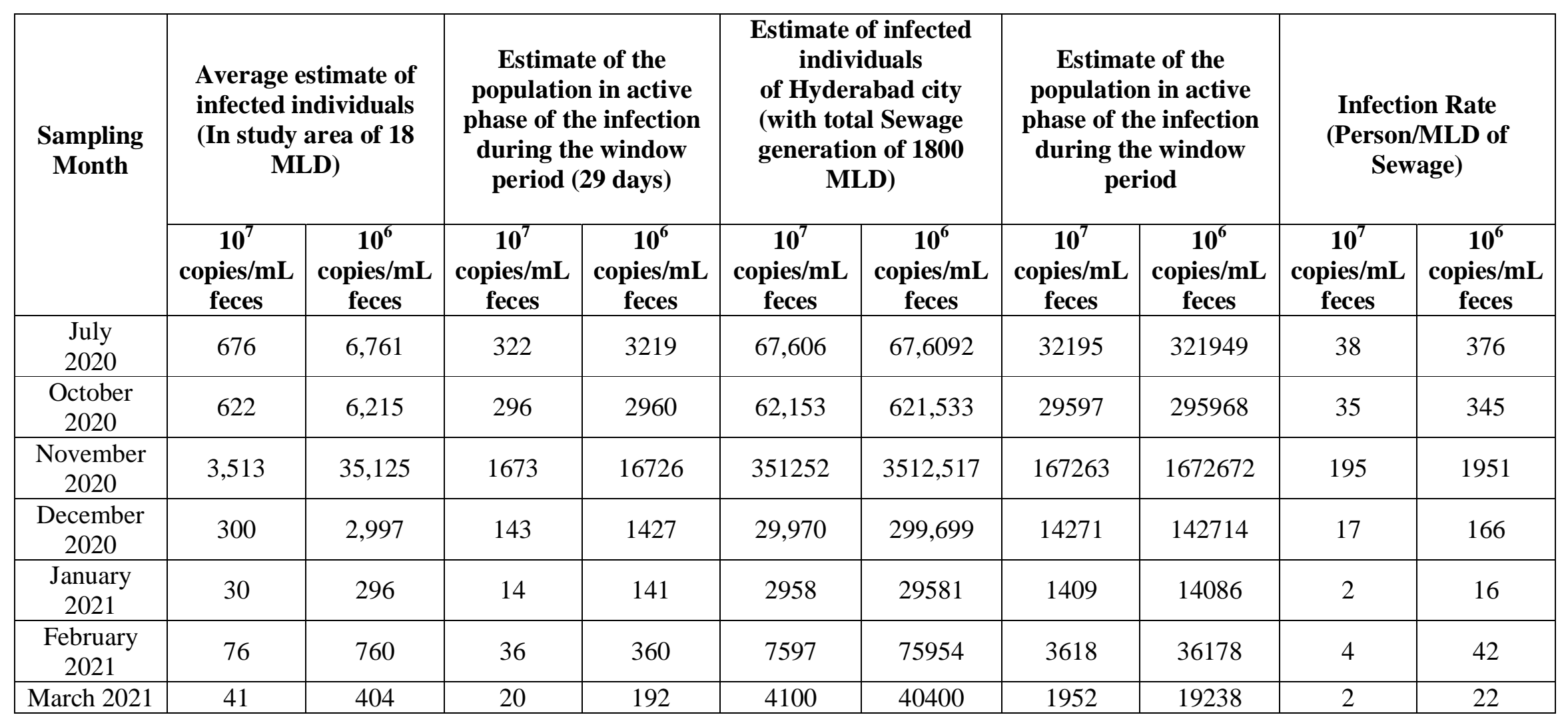


The WBE studies of infectious pathogens offers unbiased monitoring of infection prevalence, spreading rate, and dynamics of infection in terms of special and temporal avenues. In conclusion, WBE studies offers an early warning system as well as provides clear view of infection dynamics and immunity status of the population, as asymptomatic, symptomatic, and pre-symptomatic individuals shed virus and the findings are unbiased. Performing WBE studies can be extended to the surveillance of other enteric infectious pathogen as the method is simple to perform yet efficient enough to help understand the infection type and dynamics among the population in a temporal manner.

\section{Authorship contribution statement}

Athmakuri Tharak: Methodology, Investigation, Data curation, Writing - original draft. Harishankar Kopperi: Methodology, Investigation, Writing - original draft. Manupati Hemalatha: Methodology, Investigation, Data curation, Writing - original draft. Uday Kiran: Methodology, Investigation, Data curation, Writing - original draft. C.G. Gokulan: Methodology, Investigation, Formal analysis, Writing - original draft. Shivranjani Moharir: Methodology, Investigation. Rakesh K. Mishra: Conceptualization, Supervision, Funding acquisition, Validation, Writing - review \& editing. and S. Venkata Mohan: Conceptualization, Methodology, Supervision, Validation, Writing - original draft, Writing review \& editing.

\section{Declaration of competing interest}

The authors declare that they have no known competing financial interests or personal relationships that could have appeared to influence the work reported in this paper. 


\section{Acknowledgments}

The work was supported by Council of Scientific and Industrial Research (CSIR), New Delhi, India in the form of project entitled 'Testing for COVID-19 in wastewater as a community surveillance measure (6/1/COVID-19/2020/IMD)'. UK thanks UGC, CGG and MH thank CSIR for the financial support received. KH, AT, MH and SVM acknowledge the Director, CSIR-IICT for the support.

\section{References}

1. A. Venugopal, H. Ganesan, S.S.S. Raja, V. Govindasamy, M. Arunachalam, A. Narayanasamy, P. Sivaprakash, P.K. Rahman, A.V. Gopalakrishnan, Z. Siama and B. Vellingiri, Novel wastewater surveillance strategy for early detection of COVID-19 hotspots, Curr Opin Environ Sci Health, 2020, 17, 8-13.

2. A.G. Shaw, M. Majumdar, C. Troman, Á. O’Toole, B. Benny, D. Abraham, I. Praharaj, G., Kang, S. Sharif, M.M. Alam and S. Shaukat, Rapid and sensitive direct detection and identification of poliovirus from stool and environmental surveillance samples by use of nanopore sequencing, J. Clin. Microbiol., 2020., 58(9).

3. APHA. 2017. Standard methods for the examination of water and wastewater. American Public Health Association (APHA), Washington, DC, USA

4. C.G. Daughton, Monitoring wastewater for assessing community health: sewage chemical-information mining (SCIM), Sci. Total Environ., 2018, 619-620 748-764.

5. D. Barcelo, An environmental and health perspective for COVID-19 outbreak: meteorology and air quality influence, sewage epidemiology indicator, hospitals disinfection, drug therapies and recommendations, J. Environ. Chem. Eng., 2020, 8(4), 104006. 
6. F. Wu, J. Zhang, A. Xiao, X. Gu, W. L. Lee, F. Armas, K. Kauffman, W. Hanage, M. Matus, N. Ghaeli, N. Endo, SARS-CoV-2 titers in wastewater are higher than expected from clinically confirmed cases, Msystems, 2020, 5(4).

7. G. La Rosa, M. Iaconelli, P. Mancini, G.B. Ferraro, C. Veneri, L. Bonadonna, L. Lucentini and E. Suffredini, First detection of SARS-CoV-2 in untreated wastewaters in Italy, Sci. Total Environ., 202, 139652.

8. G. Medema, L. Heijnen, G. Elsinga, R. Italiaander, and A. Brouwer, Presence of SARSCoronavirus- 2 in sewage, MedRxiv., 2020, DOI: 10.1021/acs.estlett.0c00357.

9. H. Asghar, O.M Diop, G. Weldegebriel, F. Malik, S. Shetty, L. El Bassioni, A.O. Akande, E. Al Maamoun, S. Zaidi, A.J. Adeniji and C.C. Burns, Environmental surveillance for polioviruses in the Global Polio Eradication Initiative, J. Infect. Dis., 2014, 210.

10. H. Kopperi, A. Tharak, M. Hemalatha, U. Kiran, C.G. Gokulan, R.K. Mishra and S.Venkata Mohan Methodological Approach for Wastewater Based Epidemiological Studies for SARS-CoV-2, medRxiv. 2021. DOI: doi.org/10.1101/2021.02.17.21251905.

11. I. Xagoraraki, and E. O'Brien, Wastewater-based epidemiology for early detection of viral outbreaks, Springer water quality, 2020, 75-97.

12. J. Brainard, K. Pond, P.R. Hunter, Censored regression modeling to predict virus inactivation in wastewaters, Environ. Sci. Technol., 2017, 1795-1801.

13. J. Peccia, A. Zulli, D.E. Brackney, N.D. Grubaugh, E.H. Kaplan, A. CasanovasMassana, A.I. Ko, A.A. Malik, D. Wang, M. Wang and J.L. Warren, Measurement of SARS-CoV-2 RNA in wastewater tracks community infection dynamics, Nat. Biotechnol. 2020, 38(10), 1164-1167. 
14. J. Torrey, U. Gunten, T. Kohn, Differences in viral disinfection mechanisms as revealed by quantitative transfection of echovirus 11 genomes, Appl. Environ. Microb., 2019, 85 (14) 00961-1019.

15. J. Weidhaas, Z. Aanderud, D. Roper, J. VanDerslice, E. Gaddis, J. Ostermiller, K. Hoffman, R. Jamal, P. Heck, Y. Zhang, and K. Torgersen, Correlation of SARS-CoV-2 RNA in wastewater with COVID-19 disease burden in sewersheds, 2020. DOI: 10.21203/rs.3.rs-40452/v1

16. J.A. Lednicky, S.N. Shankar, M.A. Elbadry, J.C. Gibson, M.M. Alam, C.J. Stephenson, A. Eiguren-Fernandez, J.G. Morris, C.N. Mavian, M. Salemi and J.R. Clugston, Collection of SARS-CoV-2 virus from the air of a clinic within a university student health care center and analyses of the viral genomic sequence, Aerosol Air Qual. Res., 2020, 20.

17. K. Dhama, S.K. Patel, M.I. Yatoo, R. Tiwari, K. Sharun, J. Dhama, S. Natesan, Y.S. Malik, K.P. Singh, and H. Harapan, SARS-CoV-2 existence in sewage and wastewater: A global public health concern?, J. Environ. Manage., 2021, 280, 111825.

18. K. Mao, H. Zhang, Z. Yang, Can a paper-based device trace COVID-19 sources with wastewater-based epidemiology, Environ. Sci. Technol., 2020, 54, 7, 3733-3735.

19. K.M. O'Reilly, D.J. Allen, P. Fine and H. Asghar, The challenges of informative wastewater sampling for SARS-CoV-2 must be met: lessons from polio eradication, The Lancet Microbe, 2020 1(5), 189-190.

20. L.M. Casanova and S.R. Weaver, Inactivation of an enveloped surrogate virus in human sewage, Environ. Sci. Technol. Lett., 2015, 2, 76-78.

21. M. Elsamadony, M. Fujii, T. Miura and T. Watanabe, Possible transmission of viruses from contaminated human feces and sewage: Implications for SARS-CoV-2, Sci. Total Environ. 2021, 755, 142575. 
22. M. Hellmér, N. Paxéus, L. Magnius, L. Enache, B. Arnholm, A. Johansson, T. Bergström and H. Norder, Detection of pathogenic viruses in sewage provided early warnings of hepatitis A virus and norovirus outbreaks, Appl. Environ. Microbiol., 2014, 80(21), 6771-6781.

23. M. Hemalatha, U. Kiran, S.K. Kuncha, H. Kopperi, C.G. Gokulan, S.Venkata Mohan, R.K. Mishra, Surveillance of SARS-CoV-2 spread using wastewater-based epidemiology: Comprehensive study. Sci. Total Environ., 768, (2021), 144704.

24. M. Usman, M. Farooq and K. Hanna, Existence of SARS-CoV-2 in wastewater: implications for its environmental transmission in developing communities, Environ. Sci. Technol., 2020, 54, 7758-7759.

25. N. Alygizakis, A.N Markou, N.I. Rousis, A. Galani, M. Avgeris, P.G. Adamopoulos, A. Scorilas, E.S. Lianidou, D. Paraskevis, S. Tsiodras and A. Tsakris, Analytical methodologies for the detection of SARS-CoV-2 in wastewater: Protocols and future perspectives, TRAC- Trend Anal Chem., 2020, 134, 16125.

26. O.E. Hart and R.U. Halden, Computational analysis of SARS-CoV-2/COVID-19 surveillance by wastewater-based epidemiology locally and globally: feasibility, economy, opportunities and challenges, Sci. Total Environ., 2020, 730, 138875.

27. P. Foladori, F. Cutrupi, N. Segata, S. Manara, F. Pinto, F. Malpei, L. Bruni, G. La Rosa, SARS-CoV-2 from faeces to wastewater treatment: what do we know? A review, Sci. Total Environ. (2020) 140444.

28. P.M. Gundy, C.P. Gerba and I.L. Pepper, Survival of corona viruses in water and wastewater, Food Environ. Virol. 2009. 1(1), 10-14.

29. R.S. Quilliam, M. Weidmann, V. Moresco, H. Purshouse, Z. O'Hara and D.M. Oliver, The environmental implications of shedding SARS-CoV-2 in human faeces, Environ. Int., 2020. 
30. S. Venkata Mohan, M. Hemalatha, H. Kopperi, I. Ranjith and A.K. Kumar, SARS-CoV2 in environmental perspective: Occurrence, persistence, surveillance, inactivation and challenges, Chem. Eng. J., 2021, 405, 126893.

31. S. Westhaus, F.A. Weber, S. Schiwy, V. Linnemann, M. Brinkmann, M. Widera, C. Greve, A. Janke, Hollert, H., Wintgens, T. and Ciesek, S., Detection of SARS-CoV-2 in raw and treated wastewater in Germany-suitability for COVID-19 surveillance and potential transmission risks, Sci. Total Environ., 2021., 751, 141750.

32. S. Wurtzer, V. Marechal, J.M. Mouchel, Y. Maday, R. Teyssou, E. Richard, J.L. Almayrac, L. Moulin, Evaluation of lockdown impact on SARS-CoV-2 dynamics through viral genome quantification in Paris wastewaters, MedRxiv., 2020, DOI: doi:https://doi.org/ 10.1101/2020.04.12.20062679.

33. T. Nakamura, M. Hamasaki, H. Yoshitomi, T. Ishibashi, C. Yoshiyama, E. Maeda, N. Sera, H. Yoshida, 2015. Environmental surveillance of poliovirus in sewage water around the introduction period for inactivated polio vaccine in Japan. Appl. Environ. Microbiol. 81(5), 1859-1864.

34. T. Yonar, Ö. Sivrioğlu and N. Özengin, Physico-chemical treatment of dairy industry wastewaters: A review. Technological approaches for novel applications in dairy processing, 2018. 179.

35. W. Ahmed, A. Bivins, P.M. Bertsch, K. Bibby, P.M. Choi, K. Farkas, P. Gyawali, K.A. Hamilton, E. Haramoto, M. Kitajima and S.L. Simpson, Surveillance of SARS-CoV-2 RNA in wastewater: Methods optimisation and quality control are crucial for generating reliable public health information, Cur. Opi. Environ. Sci. Health., 2020a, 17, 82-93

36. W. Ahmed, N. Angel, J. Edson, K. Bibby, A. Bivins, J. W. O'Brien, P. M. Choi, M. Kitajima, S. L. Simpson, J. Li, B. Tscharke, First confirmed detection of SARS-CoV-2 
medRxiv preprint doi: https://doi.org/10.1101/2021.03.15.21253574; this version posted March 16, 2021. The copyright holder for this preprint (which was not certified by peer review) is the author/funder, who has granted medRxiv a license to display the preprint in perpetuity. All rights reserved. No reuse allowed without permission.

in untreated wastewater in Australia: a proof of concept for the wastewater surveillance of COVID-19 in the community. Sci. Total Environ. 2020b, 728, 138764.

37. W. Randazzo, P. Truchado, E. Cuevas-Ferrando, P. Simón, A. Allende and G. Sánchez, SARS-CoV-2 RNA in wastewater anticipated COVID-19 occurrence in a low prevalence area, Water Res., 2020. 181, 115942, 2020.115942. 